UDC 378.147.88

DOI https://doi.org/10.32840/1992-5786.2021.74-2.23

K. M. Havrylenko

Candidate of Pedagogical Sciences, Senior Teacher at the Linguistics Faculty National Technical University of Ukraine "Igor Sikorsky Kyiv Polytechnic Institute"

D. S. Prykhodko

Teacher at the Faculty of Linguistics National Technical University of Ukraine "Igor Sikorsky Kyiv Polytechnic Institute"

\title{
DISTANCE LEARNING TECHNOLOGIES FOR SELF-EDUCATION ORGANIZATION AT HIGHER INSTITUTIONS
}

New approaches to the organization of training and the use of distance technologies, in particular, require a significant rethinking and adjustment of traditional educational forms, and their transition into distance format. In the modern educational process, the student is not a simple consumer of information, but a creative knowledge receiver. At the same time, the task of the teacher is not only to transfer the information as a final truth but to encourage students on completing cognitive tasks independently for lifelong professional skills development. The organization of self-studying activities is an effective means of enhancing the students' independence.

The main aspects of self-studying activities have been defined in the paper as a specially organized independent work determined by specific educational goals and the contribution of self-studying to lifelong learning was considered. A brief overview of scientific literature on the problem of self-education and selfstudying as a part of the students' independent work in the system of university training is given. The crucial role of students in the self-education without the direct participation of the teacher organization is regarded as vital for the self-development and further ability to learn throughout the whole life.

The paper emphasizes that distance learning is the most suitable for the students' independent work without the direct contacts of the teachers and thus providing self-studying opportunities within the university training program. The advantages and disadvantages of synchronous and asynchronous types of distance learning for the students' self-studying possibilities have been described. Asynchronous learning despite the high requirements for self-control and self-organization is the most beneficial for the development of selfeducational conditions.

The shifting of the teacher's role in the distance form of self-studying organization from the organizing to facilitating and moderating figure for the revealing of the students' inner potential has been stressed as well as the increasing importance of the teacher's technical guidance for students has been considered. Some types of self-studying activities suitable for implementing in distance learning have been suggested. A conclusion has been drawn about the great importance of the suitability of asynchronous distance learning for self-education within university training process as a central leading form of student professional education.

Key words: distance education, distance learning, independent work professional education, professional training, self-education, self-studying, university.

Problem statement. Self-education is an inevitable part of specialist training for every student and is determined by the curriculum. It usually takes from one to two-thirds of total educational time. The self-education is only effective when it is organized systemically throughout the entire period of the students' training. For the independent cognitive activity optimization, the students write individual working plans, which permit them to distribute studying time for achieving the desired result.

Self-studying activities are regarded as a part of self-education and considered as purposeful specific independent work without outside help, for aimed knowledge and skills acquirement, and for contributing to the students' self-development. Like any activity, self-learning has its structure based on inner motivation, learning assignments, assessment and self-assessment. Such activity is prompted by specific goals reflecting the students' ideas of the educational results and takes the form of self-education. An important aspect of self-studying is that it solves not only educational tasks, but also contributes to the students' selfdevelopment and self-improvement. Consequently, the question of self-education organization in the process of quickly developing distance learning is crucial for successful professional training at modern universities.

Relevant studies analysis. Self-education is a multidimensional concept. The dictionary defines selfeducation as knowledge acquisition by independent study outside an educational institution, without a teacher's help [1, p. 41]. In a narrower sense, selfeducation is understood as any type of knowledge acquisition associated with the student's independent work on the material being studied. 
Self-education, according to M. Kasyanenko, is a purposeful process of independent acquisition of a holistic system of knowledge and skills, views and beliefs, gaining experience in a certain field of activity according to personal and public interests [2]. L. Sysoyeva points out, that self-education correspond to the social demands for constantly developing professional competence where the self-education and self-education are in the first place [3, p. 46]. L. Luzan emphasizes that selfeducation as a need for any creative and responsible professional [4]. V. Kan-Kalyk derives the concept of self-education as "a purposeful cognitive activity organized by the teacher, for gaining the general experience, methodological and special knowledge, professional skills and abilities necessary for the pedagogical process improvement" [5].

P. Sukhanov emphasizes that self-education motivation is related to the individual level of development, education and qualifications. It could be developed with the expansion of personal social interaction and the increase of social activities. In the author's opinion, self-education is characterized by the students' independency without the direct guidance of the teacher and regardless of the requirements of any educational institution. Knowledge acquisition is realized through independent work as an additional activity to the main studying activities, and organized under the influence of internal stimuli [6].

S. Brookfield points out that self-education is an activity controlled by the person with developed critical insight and reflective analysis independently. He emphasizes that self-educational activities should include not random, episodic and additional actions, but the purposeful, systematic, cognitive process of setting goals and means of their achievement [7, p. 19-32].

Self-education in the works of M. Gibbons is defined as the process of conscious knowledge and skills acquisition initiated by an individual concerning the subject of study, extend and sources of information, setting the time of learning, and identifying the forms of needs and interests [8].

C. Hamm emphasizes that self-education "is a positive stride forward in helping students adjust to adult society and the world of work" requiring an independent, self-controllable personal transformation influenced by the radical impact of general and professional education [9, p. 1].

Thus, self-education, according to many scientists, differs from organized academic education by the absence of the external control and obligatory class meetings. Self-education always has a specific goal determined by the subject, content, conditions and means of teaching.

The aim of the paper. The purpose of the article is to study the possibilities of distance education technologies in organizing effective self-studying activities as a main aspect of self-education process at higher educational institutions.

Presentation of the main research material. One of the main tasks of the modern education system is to create conditions for the holistic development of an individual. Strengthening the selfeducation role in the process of teaching contributes to the implementation of these conditions. The Law of Ukraine on Education states that education is the basis of individual intellectual, physical and cultural development for successful social growth, economic well-being, and the key to the development of a society and state united by common values and culture [10].

In traditional university education, various types of self-study activities are organized as a student's independent work aimed at the development of professional and individual skills, carried out in the classroom and outside. As a rule, independent work is additional and is aimed at the consolidation of the main learning activities. According to A. Kuzminsky, the student's independent work is "a planned educational activity performed according to the task, under the methodical guidance and control of the teacher, but without her direct participation" [11, p. 309]. At the same time, independent work is usually understood as students' activity organized by a teacher, aimed at fulfilling the didactic goals in a specially allotted time (knowledge consolidation, skills development, material revision). Independent work, as a didactic phenomenon, is, on the one hand, an educational task, i.e. what the student must accomplish, on the other hand, an educational task fulfilment, which ultimately leads either to a new knowledge/skills obtaining, or already acquired knowledge/skills expanding. Accordingly, self-study is assumed to be a learning tool for obtaining some level of acquisition for a certain type of cognitive tasks solving and for rising from lower to higher levels of individual and professional skills; and to develops a psychological attitude towards systematic independent work for new knowledge and skills development from scientific and public data.

Self-study has always been an indispensable part of education, but, according to practical observations, it does not necessarily ensure the achievement of the educational results. It rather indicates the students' readiness for further self-education and self-development, professional and personal selfimprovement, which is the most vital condition of lifelong education. Accordingly, the self-study possesses a significant potential for self-education. It is quite true that motivation, purposefulness, as well as self-organization, independence, self-control and other personal qualities can be developed as a result of self-studying activities and can serve as the basis for students' position in the educational process.

One of the important questions is the organization of self-education. First of all, it should be purposeful 
and motivating, structured and planned by the students alone or in cooperation with the teachers, performed and corrected in the process and evaluated according to the results. The successful self-education organization requires a sufficiently high level of self-awareness, self-discipline, and personal responsibility.

Therefore, the role of student in the organization of self-education is crucial as the most important tool of pedagogical management of the student's independent cognitive activity in the learning process [12]. As an element of this process, it must correspond to a specific didactic goal and task but, at the same time, with the guiding role of the teacher. The growing importance of independent work at the present stage of higher education development the students' activities take place without the direct guidance of the teacher, although organized and managed by her [13]. Only an independent work performed without the direct participation of the teacher permits students to develop such personality traits as independence, initiative, which lead to the growth of self-organization, self-control, the ability for self-development and self-improvement.

For self-education the students need not only to understand the learning goals but also to follow them, and to accommodate their activity accordingly, which presupposes the developed ability to program an independent activity in relation to the corresponding goals, to select the appropriate learning methods, and to determine the sequence of individual actions. Also for the successful realization of the self-studying activities, an ability to evaluate the intermediate and final results objectively is important as well as to correct them in order to meet the set goals and learning requirements.

Consequently, the organization of self-study is dependent on the personal students' abilities of selforganization, a high level of self-awareness and selfesteem, reflexive thinking, independence, which are the main qualities signalling individual's readiness for self-education.

Nowadays, new trends in education are aimed at using the latest teaching technologies for fast implemented nowadays distance learning. Distance learning is entirely based on the students' independent work with the purposeful teacher's guidance. During the last decades due to the quick development of computer technologies, within the framework of traditional higher education, the new forms of distance learning have been developed. The recent technical and technological modernization of education has created optimal conditions for the various types of online activities supported by computer technologies into the educational process. The situation with the quick spreading of pandemic during the last months forced the transition to the distance forms of education.
Distance learning or distance education, (also called e-learning, and online learning) is "a form of education in which the main elements include physical separation of teachers and students during instruction and the use of various technologies to facilitate student-teacher and student-student communication" [14].

Unlike traditional forms of higher education, distance learning is based on the latest ICT capabilities and do not imply the direct contact between teachers and students, providing them with a training opportunity without visiting an educational institution. A developed resources base for distance learning at the university, which include access to the appropriate technological tools and equipment, suitable teaching methods, prepared teaching and administrative staff, also provides opportunities for the implementation of self-education relied on individual learning coordinated and guided by the teacher.

In distance learning, the participants' interaction in the educational process is always mediated by computer-supported means, but it can be synchronized in time (synchronous) or not (asynchronous). It is important to distinguish between these types of distance learning due to the fact that they use different communication approaches and characterized by the use of different technical means for educational content transmission.

For synchronous learning, video communication is the most common form of interaction. Such learning can be carried out as video conferences and meetings, video calls, online chats and other, which are examples of synchronous approach or a direct exchange of information between the participants, interaction in a real-time. Consequently, the subjects of educational process can instantly exchange opinions, ask questions and get the answers. The student's presence is recorded and registered. Obviously, the synchronous approach practically erases the line between classroom and virtual teaching, and thus ensures the maximum approximation to the conditions of the traditional fulltime education.

Asynchronous learning, in contrast, does not imply regular direct online participants' interaction. In this case, the student has only clear terms set for studying certain educational materials, submitting assigned works, passing tests and exams. The students are responsible for the organization of his/her individual educational process depending on the time and conditions available for studying. Asynchronous learning mainly employs e-mail, mailing lists, discussion panels, wiki systems, blogs and other. In the university learning the most widely used resources are video recordings of lectures, recorded video messages, discussion boards, messengers, forums, and e-mails. The recordings of synchronous online resources (video conferences, 
online meetings, etc.) are also used to facilitate information exchange between students, as well as between students and teachers. The asynchronous approach is not dependant on time or time zones.

Each approach has its advantages and disadvantages. Synchronous distance learning is primarily associated with technical difficulties as it puts a heavy load on the network and requires a stable connection. In this case, the student may temporarily drop out of the lesson and lag behind, since it takes time to reconnect. Moreover, synchronous participation often requires the additional equipment, which is often expensive.

Asynchronous learning might seem complicated due to the lack of a common learning space, absence of the direct communication with teachers and other students, the necessity to understand and learn a huge amount of information unassisted and personal organizing efforts. Therefore, asynchronous learning requires from the students the utmost purposefulness, learning independence and self-organization.

With the distance learning prevailing in the current conditions, the emphasis on independent work changes the role of the teacher in the learning process. In asynchronous learning, it is reduced to the function of a facilitator or moderator. These roles are based on the use of special techniques that facilitate the process of communication for students' acquired opinions an estimations exchange, which brings them to a competent decision making. The moderated group meeting moderation is aimed at the revealing of the students' inner potential, not for introducing something new, but only for making the acquired knowledge relevant.

The role of a teacher-moderator in asynchronous distance learning implies the: creating and administering a virtual didactic environment, setting for communication in a virtual environment, providing asynchronous feedback, maintaining pedagogical discourse. The creation of a virtual didactic environment includes, in some cases, the organization of a virtual classroom, the engagement of students employing the elements of synchronous and asynchronous online learning. A properly designed virtual environment is usually similar to a real classroom with minimizes interferences and educational material presentation. This requires from the teacher both general technical skills for electronic presentation material preparation and knowledge of software platforms suitable for training organization and provision.

The forms of self-studying offered in traditional education include projects, essays, theses and annotation writing, note-taking, peer reviews, feedback, problem-solving, diagrams and tables drawing, graphic and computational works, independent tests, individual creative tasks, and other tasks corresponding to the faculty specifics.
Conclusions. Asynchronous distance learning is the most suitable for self-education, as a part of university training. However, its specifics within the framework of asynchronous learning acquire completely different functions. The self-education is no longer only a range of additional assignments for knowledge increasing insight and concretization with the teacher's pedagogical guidance and management. The self-studying in asynchronous mode is positioned as a central leading form of student learning. The asynchronous distance learning is suitable for the development of students' self-educational skills and abilities.

The self-studying as a part of self-education is a special form of educational activity aimed at the development of the students' independence in knowledge acquisition, skills and abilities training, carried out as a form of distance learning under the conditions of different electronic learning tools implementation. It makes it possible to bring educational activities closer to future professionals through the system of specially designed typical training tasks in a specific discipline in higher education.

\section{References:}

1. Slovnyk ukrayinskoyi movy: $v 11 \mathrm{t}$. [Dictionary of the Ukrainian language: in 11 vols.]: Dictionary. Vol. 9. Kyiv : Institute of Linguistics, 1980. P. 41 [in Ukrainian].

2. Kasyanenko M.D. Samostoyatelnaya rabota studenta : uchebnoye posobye dlya slushatelej FPK vuzov [Independent student work: textbook. Manual for students of FPK universities]. Kyiv : UMK VO, 1988. 280 p. [in Russian].

3. Sysoeva L. Neperervna osvita v Ukrayini: yiyi skladovi i tendenciyi rozvytku [Continuing education in Ukraine: its components and development trends]. Postgraduate education in Ukraine. 2011. No. 1. P. 46 [in Ukrainian].

4. Lusan L. Innovacijna osvitnya diyalnist: rehionalni aspekty [Innovative educational activity: regional aspects: abstracts of International. scientificpractical conf.]. 2011. P. 220 [in Ukrainian].

5. Кап-КаІук В.A. Uchytelyu o pedahohycheskom obshhenyy [To the teacher about pedagogical communication]. Moscow, 1987 [in Russian].

6. Sukhanov P., Nurulin R. Motyvacyya samoobrazovatelnoj deyatelnosty studentov kak pedahohycheskaya problema [Motivation of selfeducational activity of students as a pedagogical problem]. Modern science-intensive technologies. 2016. No. 12-3. P. 632-636. URL: http://www.toptechnologies.ru/ru/article/view?id=36541 (Last accessed: 23.01.2021) [in Russian].

7. Brookfield S.D. Self-Directed Learning: A Conceptual and Methodological Exploration. Studies in the Education of Adults. 1985. No. 17/1. P. 19-32. 
8. Gibbons M., Phillips G. Self-Education: The Process of Life-Long Learning. Canadian Journal of Education / Revue canadienne de l'éducation. 1982. Vol. 7, No. 4. P. 67. URL: https://doi.org/10.2307/1494774 (Last accessed: 23.01.2021).

9. Hamm C. Critique of Self-Education. Canadian Journal of Education / Revue canadienne de l'éducation. 1982. Vol. 7, No. 4. P. 87. URL: https://doi.org/10.2307/1494775 (Last accessed: 23.01.2021).

10.Law of Ukraine on Education. Verkhovna Rada of Ukraine. URL: https://zakon.rada.gov.ua/laws/ show/2145-19\#Text (Last accessed: 23.01.2021).

11. Kuzminsky A. Pedahohika vyshhoyi shkoly: Navchalnyi posibnyk [High education pedagogy:
Educational aid]. Kyiv : Znannya, 2005. 486 p. [in Ukrainian].

12.García Espinosa B.J., Tenorio Sepúlveda G.C., Ramírez Montoya M.S. Self-motivation challenges for student involvement in the Open Educational Movement with MOOC. RUSC. Universities and Knowledge Society Journal. 2015. Vol. 12, No. 1. P. 91. URL: https://doi.org/10.7238/rusc. v12i1.2185 (Last accessed: 23.01.2021).

13.A Handbook for Teaching and Learning in Higher Education. 2008. URL: https://doi. org/10.4324/9780203891414 (Last accessed: 23.01.2021).

14.Distance learning. Encyclopedia Britannica. URL: https://www.britannica.com/topic/distancelearning (Last accessed: 23.01.2021).

Гавриленко К. М., Приходько Д. С. Технології дистанційного навчання для організації самоосвіти у закладах вищої освіти

Нові підходи до організації навчання та використання дистанційних технологій, зокрема, вимагають суттєвого переосмислення та коригування традиційних форм навчання у разі переходу до дистанційного формату. У сучасному навчальному процесі студент є не простим споживачем інфрормації, а творчим одержувачем знань. Водночас завдання викладача полягає не лише у передачі інфрормації як остаточної істини, а в заохоченні студентів до самостійного виконання пізнавальних завдань для розвитку професійних навичок протягом усього життя. Організація самонавчальної діяльності є ефрективним засобом підвищення самостійності студентів.

Основні аспекти самонавчальної діяльності визначені у статті як спеціально організована самостійна робота, що характеризується конкретними освітніми иілями та розглядається як здатність до самонавчання у подальшому навчанні впродовж життя. Дано короткий огляд наукової літератури з проблеми самоосвіти та самонавчання як частини самостійної роботи студентів у системі університетської підготовки. Вирішальна роль студентів у самоосвіті без безпосередньої участі викладача розглядається як життєво важлива навичка для саморозвитку та подальшої здатності вчитися протягом усього життя.

У статті підкреслюється, що дистанційне навчання $є$ найбільщ підходящим для організації самостійної роботи студентів без безпосередніх контактів з викладачем і таким чином забезпечує можливості самостійного навчання в рамках університетської програми підготовки. Описано переваги та недоліки синхронного та асинхронного видів дистанційного навчання для можливостей самостійного навчання студентів. Асинхронне навчання, незважаючи на високі вимоги до самоконтролю та самоорганізації, описується як найбільш придатне для розвитку умов самоосвіти.

У роботі наголошується на зміні ролі викладача у дистанційній фоормі організації самонавчання 3 організатора на фрасилітатора та модератора навчання, важливого для розкриття внутрішнього потенціалу студентів, а такожзростання значення технічного керівництва викладача. Запропоновано деякі види самонавчальної діяльності, придатні для використання у процесі дистанційного навчання. Зроблено висновок про важливість асинхронного дистанційного навчання для розвитку самоосвіти студентів у рамках університетського навчального процесу як основної фоорми профресійного навчання.

Ключові слова: дистанційна освіта, дистанційне навчання, самостійна робота, професійна освіта, профресійна підготовка, самоосвіта, самонавчання, університет. 